\title{
THE EFFECT OF CONDUCTING GOBAK SODOR TRADITIONAL GAMES ON STUDENTS' BEHAVIOR IN SDN 10 MATARAM
}

\author{
Ulia Arta Sari ${ }^{1}$, Nasruddin $^{2}$, Abdul Kadir Jaelani ${ }^{3}$ \\ ${ }^{1,2,3}$ Universitas Mataram, Mataram, Indonesia
}

Article Info

Article history:

Received: 22-11-2020

Revised: 25-11-2020

Published: 10-05-2021

\section{Keywords:}

Student Behavior

Traditional Games

Gobak Sodor

\begin{abstract}
Lack of independence of students solving problems with friends while playing or when the learning process is taking place. The problems that occur often make the parents intervene. Related to this problem, there is a game method that can train student cooperation and responsibility, the game is usually called Gobak Sodor. This game has a positive impact on students' attitudes and behavior. Thus, the writer wanted to know whether there was a significant effect of giving the traditional Gobak Sodor game on student behavior. The research technique used is to use quantitative methods. The research instrument used was a questionnaire. The data analysis technique used paired sample t-test, based on the results of the pretest and post-test, the average value of student behavior was 42.97 and the post-test was 46.94 . The results of hypothesis testing obtained the value of Sig. (2-tailed) $<0.05$ at the pretest and post-test with a value of $0.000<0.05$. In accordance with hypothesis testing, namely the value of Sig. (2-tailed) $<0.05$, then Ho is accepted and $\mathrm{Ha}$ is rejected. This shows that there is an effect of giving the traditional Gobak Sodor game on student behavior.
\end{abstract}

This is an open access article under the CC BY-SA license.

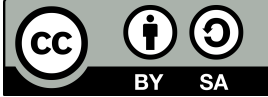

\section{Corresponding Author:}

Ulia Arta Sari,

Elementary Education Study Program, Faculty of Teacher Training and Education, Universitas Mataram,

J1. Brawijaya No. 22, Mataram, Indonesia.

Email: uliaartasari@gmail.com

\section{INTRODUCTION}

Education is a form of human culture that is dynamic and full of development. Changes or developments in education must be in line with cultural changes. Education is also interpreted as an effort to help students develop their potential to face the future. There are two important things that must be realized in the process of implementing education, namely developing the abilities of students and shaping the character of students (Susanti, Saputra, \& Setiawan, 2021).

Children world is the world of play. Playing activities can actually provide many benefits for students (Erfan, Widodo, Umar, Radiusman, \& Ratu, 2020). Through playing (games), the children will learn various things, including learning to know the environment around him along with mastering some life skills such as language skills, socializing and others. Games can foster children's fun and satisfaction. Hotimah et al (2021) in addition, stated there are many important benefits that result from doing games, including socialization, learning tools, emotional expression, moral, physical and personality development. The games re chosen by themselves without any element of coercion moreover they feel happy when doing them. Sidiq et al (2020) said that playing games is an activity that is very important in the learning process of children, through playing 
games, children will be encouraged to experiment and grow well in their life. Children's playing activity can be facilitated with various types of media and types of games (Vingki, An'nur, \& Salam, 2016).

There are the many types of children's games in Indonesia. There are two types of them, namely traditional games and modern games. However, in its development, traditional games are currently getting marginalized and their popularity has been shifted by the presence of modern games (Affandi, Saputra, \& Husniati, 2020). One of the symptoms that has emerged in the last three decades in Indonesia is the proliferation of various forms of toys and games originating from abroad, which of course has shifted the popularity of traditional games among children (Juliansyah, Darmiany, \& Husniati, 2021). The fast-paced modernization has made modern games develop rapidly with increasingly varied types, traditional games are now being marginalized, left behind, and even forgotten. Starting from children to adults, they are now enjoying playing in front of TV screens, computers and mobile phones (Francová, 2014). The influx of foreign gaming is felt increasingly in line with the opening of electronic game venues in many shopping centers. Traditional games are symbols of hereditary knowledge and have various cultural values contained in them. Traditional games can train children's social emotional skills, because in general traditional games are games that require more than one player, one of which is the Gobak Sodor game (Mustaghfiroh, 2020).

The Gobak Sodor game is a game played in groups. This game is played with at least 6 people per group. This game is played through checkered lines on a yard. SDN 10 Mataram often chooses the traditional Gobak Sodor as a routine game in athletics subjects. Based on the field fact analysis that the researcher conducted and found several behavioral problems in grade 5 at SDN 10 Mataram. The first problem was that children had difficulty concentrating and liked to disturb their friends during lessons or outside the classroom. When lessons are in progress, researchers notice that some students are standing up from his seat to disturb and persuade friends to chat so that it disturbs other students (Maboe, 2017). That behavior often causes fights with other friends. The second problem is that students are not independent in solving problems. This is proven when the child encounters problems at school - either when learning is taking place or when playing outside the classroom - when the child cannot solve his or her own problems, the child complains to his parents so that the child's parents come to school to solve the child's problem (Salavera, Usán, \& Teruel, 2019).

Based on this problem, it can be seen that the behavior of the children and the actions of the parents cause the children to become dependent. This was also reinforced from the results of interviews with athletics teachers at SDN 10 Mataram that some students were less able to control their behavior both when inside and outside the learning process. Based on the description above, the researcher is interested in seeing the behavior that results from traditional games. On that basis, this study entitled "The Effect of Conducting Traditional Gobak Sodor Games on Student Behavior at SDN 10 Mataram Academic Year 2019/2020".

\section{RESEARCH METHOD}

This research is a quantitative study because this research was conducted using numbers, statistical management, structure, and controlled experiments. The method used is the experimental method, which is research conducted by researchers to determine the level of influence between two or more variables, without making changes, additions or manipulations to existing data (Suharsimi, 2013). The research used two variables, namely the independent variable (independent) and the dependent variable (dependent). The independent variable $(X)$ in this study is the provision of the traditional gobak Sodor game. The dependent variable $(Y)$ is the behavior of students at SDN 10 Mataram.

The research was conducted on $5^{t h}$ grade students at SDN 10 Mataram in September 2020. The sample of this study was 24 students from a population of 73 students. The final step, student sampling for each school in this study uses probability sampling where each student has the opportunity to be selected as the sample. Sampling was done by using simple random sampling technique. Sugiyono (2019) explains that the simple random sampling technique is a technique that requires a random sampling of members without paying attention to the strata in the population. Simple random sampling is used when the population is considered homogeneous. Sampling in the two classes was carried out randomly by way of a lottery or by drawing student attendance numbers. The method of this lottery is to write the student's attendance number on small paper and then roll the paper. Without prejudice, paper rolls were taken according to the desired sample size, so that the attendance numbers printed on the rolls of paper taken were decided to be the subject of research.

The research instrument used in this study using a questionnaire in the form of a statement of students' positive behavior. The type of questionnaire used is a closed questionnaire, that is, a questionnaire that has 
provided the answer so that the respondent just chooses which one is closer to his/her condition. The goal is to measure students' behavior. Sugiyono (2019) states that it is suggested that an adequate number of questions is between 20 to 30 questions. Therefore, the authors made a questionnaire in this study is 30 statement items. This instrument uses a scale, which has answers with gradations from Always (SL), Often (SR), Rarely (J), Very Rarely (JS), and Never (TP).

The data analysis technique used in this study was paired sample t-test. Paired samples can be defined as samples with the same subject but have undergone two different treatments. SPSS 25 software was used to calculate the value of the paired sample t-test in this study.

\section{RESULT AND DISCUSSION}

\subsection{Result}

Based on the results of the research that has been done, the results in the pretest and post-test of student behavior are obtained:

Table 1. Pre-test and Post-test Data of Students' Behavior

\begin{tabular}{lccc}
\hline & & Pre-test & Post-test \\
\hline $\mathrm{N}$ & Valid & 72 & 72 \\
& Missing & 0 & 0 \\
Mean & 42.97 & 46.94 \\
Median & & 43.00 & 47.00 \\
Mode & 43 & 47 \\
Minimum & 38 & 43 \\
Maximum & 48 & 50 \\
Percentage(\%) & $86 \%$ & $94 \%$ \\
\hline
\end{tabular}

Based on the pretest data, it is known that the mean is 42.97 , the median is 43.00 , the mode is 43 , the minimum value is 38 , the maximum value is 48 and the average value in the form of a percentage is $86 \%$. While the post-test data shows that the mean is 46.94 , the median is 47.00 , the mode is 47 , the minimum is 43 , the maximum is 50 and the percentage of mean is $94 \%$.

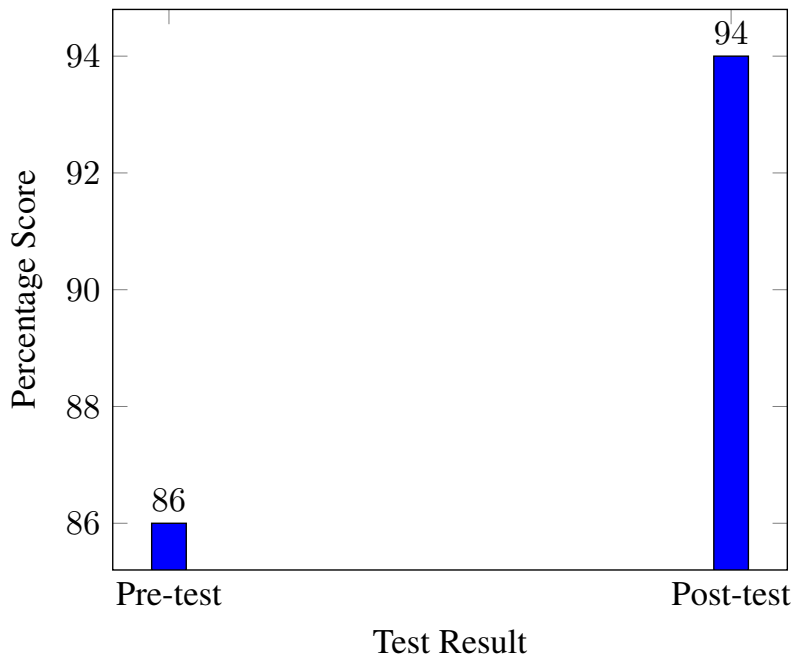

Figure 1. Data Comparison Diagram of Pretest and Posttest Results

Based on the data obtained, it can be seen that the score mean of student behavior based on three indicators (disciplinary behavior, cooperation and responsibility), the average score for the pretest is $86 \%$ and the post-test is $94 \%$.

\subsection{Discussion}

The questionnaire was given to three groups before the treatment. The score was tested for normality and the significant values are 0.200 for $X_{1} ; 0.092$ for $X_{2}$; and 0.056 for $X_{3}$. Because the significant value is 
greater than 0.05 ( $\mathrm{Sig}>0.05)$, it can be said that the three variables are normally distributed. Meanwhile, after giving the action the researcher got significant values from the $X_{1}, X_{2}$ and $X_{3}$ consecutively are $0.177,0.199$, and 0.061 . Because the significant value is greater than 0.05 ( $\mathrm{Sig}>0.05)$, it can be said that the three variables are normally distributed.

In addition to the normality test data, a homogeneity test was also carried out on three variables, namely discipline, cooperation, and responsibility. The result showed that the sig. value was 0.061 or more than 0.05 , so it can be said that the data was homogeneous. Furthermore, the results of the homogeneity test on the research variable cooperation indicator show that the sig. value is 0.437 or more than 0.05 , so it can be said that the data is homogeneous. In the homogeneity test results of the research variable responsibility indicator, it is known that the sig. value is 0.435 or more than 0.05 , so it can be said that the data is homogeneous.

Furthermore, hypothesis testing using paired sample t-test at the pretest and post-test, the value obtained on the variable $X_{1}$, the value of Sig. (2-tailed) $=0.000<0.05$ on the pretest and post-test. The variable $X_{2}$ have Sig. $(2$-tailed $)=0.000<0.05$ on the pretest and post-test at the significant level of 0.05 . The variable $X_{3}$ have value of Sig. (2-tailed) $=0.000<0.05$ on the pretest and post-test at the significant level of 0.05 . In accordance with the hypothesis testing, namely the value of Sig. (2-tailed) $<0.05$, then Ho is accepted and Ha is rejected. Based on the data in the three tables above, it can be seen that this shows that there is an effect of giving the traditional Gobak sodor game on student behavior at SDN 10 Mataram in the 2019/2020 academic year.

To strengthen this research, the traditional Gobag Sodor game theory is a game that is played in a square arena bordered by a chalk line, consisting of two teams with three guards each, one team plays as a guard and the opposing team plays as a player, alternately. Every member of the player team will try to reach the back line of the arena (the door) and the members of the guard team will prevent it. Some of the cultural noble values contained in the Gobag Sodor game are first, according to the teacher's opinion there are values of skill, discipline, vigilance, agility, accuracy, strength, unity, sports, responsibility, cohesiveness, courage, and friendship. Second, according to the public opinion there are values of honesty, agility, togetherness, discipline, mutual cooperation, unity, courage, agility, unity, leadership and cooperation. The tools used in the Gobag Sodor game (Maja, Nurhasanah, \& Husniati, 2021).

Playing is the process of student interaction with other students in situations both at school and outside of school. Based on these facts, there is a goal to be achieved is changing student behavior. In this study, researchers used traditional games, especially Gobak Sodor. This aims to improve students' ability to control behavior during socializing. Playing is a means of giving treatment which is indirectly a means that students enjoy, so that it is easier for students to understand how they should behave through activities they enjoy. The results in this study state that there is a positive and significant effect of the traditional Gobak Sodor game on student behavior at SDN 10 Mataram in the 2019/2020 academic year.

\section{CONCLUSION}

Based on the results of data analysis, hypothesis testing, and the discussion that has been stated in the previous chapter, the conclusions in this study are as follows: "There is an effect of giving the traditional Gobak Sodor game on student behavior at SDN 10 Mataram". This means that the traditional game, especially gobak sodor, is one of the right efforts to improve student behavior both at school and in the society. The data analysis technique used in this study used paired sample t-test, based on the results of the pretest and post-test, the mean of student behavior score pretest was 42.97 and post-test 46.94 . The results of hypothesis testing obtained the value of Sig. (2-tailed) $<0.05$ at pretest and post-test with a value of $0.000<0.05$. In accordance with hypothesis testing, namely the Sig. (2-tailed) $<0.05$, then $H_{0}$ is accepted and $H_{a}$ is rejected. This shows that there is an effect of giving the traditional Gobak Sodor game on student behavior.

Based on experience when carrying out research, there are suggestions that can be conveyed to improve further research, including first, parents can use the traditional Gobak Sodor game in this study as an alternative game that can have an influence on student behavior. Second, teachers and school (in general) can use the traditional Gobak Sodor game in this study as a means for students to control their daily behavior. Third, for future researchers, for future researchers who are interested in doing research with the same title as this research, so that this study becomes a reference for conducting further research more thoroughly and better. 


\section{REFERENCES}

Affandi, L. H., Saputra, H. H., \& Husniati. (2020). Apakah Tingkat Kebahagiaan Bisa Menjelaskan Hasil Belajar Siswa Sekolah Dasar? PROGRES PENDIDIKAN, 1(3), 168-176.

Erfan, M., Widodo, A., Umar, U., Radiusman, R., \& Ratu, T. (2020). Pengembangan Game Edukasi Kata Fisika Berbasis Android untuk Anak Sekolah Dasar pada Materi Konsep Gaya. Lectura: Jurnal Pendidikan, 11(1), 31-46.

Francová, L. (2014). The level of physical and social skills after completion of the training program for children aged 9-11. Acta Gymnica, 44(1), 33-45. doi:10.5507/ag.2014.004

Hotimah, H., Ermiana, I., \& Rosyidah, A. N. K. (2021). Pengembangan Multimedia Interaktif Berbasis Macromedia Flash Untuk Meningkatkan Kemampuan Komunikasi Matematis. PROGRES PENDIDIKAN, 2(1), 7-12. doi:10.29303/prospek.v2i1.57

Juliansyah, A., Darmiany, D., \& Husniati, H. (2021). Communication Relationship with The Family To The Learning Motivation Of Class IV Students of SDN Gugus 02 Kecamatan Alas In Academic Year 2019. Renjana Pendiidkan Dasar, 1(1), 23-29.

Maboe, K. A. (2017). Science Direct Use of online interactive tools in an open distance learning context : Health studies students' perspective. Health SA Gesondheid, 22(1), 221-227. doi:10.1016/j.hsag.2017.02.001

Maja, C. M. A., Nurhasanah, \& Husniati. (2021). The Influence of Group Investigation Methods on The Learning Activities of Class Iv Students Of SDN 3 Sambelia In The Academic Year 2020-2021. Renjana Pendiidkan Dasar, 1(1), 16-22.

Mustaghfiroh, S. (2020). Konsep “Merdeka Belajar” Perspektif Aliran Progresivisme John Dewey. Jurnal Studi Guru dan Pembelajaran, 3(1 SE - Articles), 141-147. doi:10.30605/jsgp.3.1.2020.248

Salavera, C., Usán, P., \& Teruel, P. (2019). The relationship of internalizing problems with emotional intelligence and social skills in secondary education students: gender differences. Psicologia: Reflexao e Critica, 32(4), 1-9. doi:10.1186/s41155-018-0115-y

Sidiq, D. A. N., Fakhriyah, F., \& Masfuah, S. (2020). Partisipasi Guru Pelaksanaan Bimbingan dan Konseling di SD Kota Mataram NTB. PROGRES PENDIDIKAN, 1(2), 99-105.

Sugiyono, S. (2019). Metode Penelitian Pendidikan. Bandung: Alfabeta.

Suharsimi, A. (2013). Manajemen Penelitian. Jakarta: PT. Rineka Cipta.

Susanti, T. C., Saputra, H. H., \& Setiawan, H. (2021). The Effect of Articulation Methods on Speaking Skills of Class III Students of SDN 28 Cakranegara. Renjana Pendidikan Dasar, 1(1), 44-49.

Vingki, L., An'nur, S., \& Salam, A. (2016). Penerapan Model Pembelajaran Kooperatif Tipe Teams Games Tournament (TGT) Menggunakan Media Permainan Monopoli Untuk Meningkatkan Aktivitas Siswa Di Kelas VIII SMP Negeri 7 Banjarmasin. Berkala Ilmiah Pendidikan Fisika, 4(1), 73-84. doi:10.20527/ bipf.v4i1.1049 